\title{
Chemical composition and organoleptic characteristics of meat from lambs supplemented with different protein sources
}

\author{
Manuel Gonzalez Ronquillo ${ }^{1}$, Esaul Jaramillo Lopez ${ }^{2}$, Maria de la Salud Rubio-Lozano ${ }^{3}$, \\ Ignacio Dominguez Vara $^{1}$ and Jose Romero Bernal ${ }^{1}$ \\ ${ }^{1}$ Universidad Autonoma del Estado de Mexico, Facultad de Medicina Veterinaria y Zootecnia, Toluca, Mexico, \\ ${ }^{2}$ Universidad Autonoma de Ciudad Juarez, Chihuahua, Mexico and ${ }^{3}$ Universidad Nacional Autonoma de Mexico, \\ Facultad de Medicina Veterinaria y Zootecnia, DF, Mexico
}

The use of forage can improve carcass quality and the acceptability of the meat to the consumer. Carcass quality is influenced by the type of feed, and supplementation with different protein sources may affect the chemical composition and characteristics of meat from $\operatorname{lambs}^{(1)}$.

The aim of the present study was to compare the organoleptic characteristics and chemical composition of meat from lambs grazing perennial ryegrass (Lolium perenne L.) and supplemented with different protein sources.

Fifteen Suffolk lambs (6 months of age) grazing ryegrass pasture for $12 \mathrm{~h}$ daily were allocated to three treatments (five lambs per treatment): T1, supplemented with ryegrass hay; T2, supplemented with a concentrate containing soyabean meal (60 g crude protein/kg); T3, supplemented with a concentrate containing fishmeal as the main protein source. Supplements were provided at $30 \mathrm{~g} / \mathrm{kg}$ body weight ${ }^{0.75}$ per $\mathrm{d}$. The lambs were slaughtered at a body weight of $50 \mathrm{~kg}$. The organoleptic characteristics of the carcass meat were assessed by thirty male subjects using a questionnaire in which each question offered five options based on the scores: 2, I dislike it; 4 , I dislike it a lot; 6, I neither like nor dislike it; 8 , I like it a little; 10, I like it a $\operatorname{lot}^{(2)}$.

There were no differences in the carcass and meat characteristics between treatments $(P>0.05$; Table). The crude protein content was higher $(P<0.05)$ for T1 and T3 than for T2, while the fat content was higher for T1.

Table. Organoleptic characteristics (scale 2-10) and chemical composition (g/100g DM) of meat from lambs supplemented with different protein sources

\begin{tabular}{lcccr}
\hline & T1 & T2 & T3 & SE \\
\hline Taste & 7.6 & 8.0 & 8.1 & 0.21 \\
Juiciness & 7.5 & 7.7 & 8.6 & 0.47 \\
Texture & 8.2 & 8.3 & 8.9 & 0.31 \\
Flavour & 7.7 & 8.0 & 7.8 & 0.12 \\
DM (g/100g) & $68.3^{\mathrm{b}}$ & $65.0^{\mathrm{a}, \mathrm{b}}$ & 1.14 \\
Ash & $0.17^{\mathrm{a}}$ & $0.20^{\mathrm{a}}$ & $0.40^{\mathrm{a}}$ & 0.03 \\
Crude protein & $54.7^{\mathrm{a}}$ & $46.5^{\mathrm{b}}$ & $52.8^{\mathrm{a}}$ & 1.48 \\
Fat & $48.4^{\mathrm{a}}$ & $46.0^{\mathrm{b}}$ & $40.3^{\mathrm{b}}$ & 1.93 \\
a,b Values with unlike superscript letters were significantly different $(P<0.05)$. & &
\end{tabular}

The results show that the organoleptic characteristics of the lamb meat were not different between treatments. This finding is similar to previous findings ${ }^{(3,4)}$, although these earlier studies did not find differences in the intensity of the taste between different treatments. However, a more-intense taste has been reported for meat from lambs fed forage compared with concentrate ${ }^{(5)}$. Although no differences were found in the organoleptic characteristics $(P>0.05)$, there were differences in the chemical composition of the meat, with an increase in the crude protein and fat contents in the meat from lambs supplemented with ryegrass hay.

J.R.B. is the recipient of UAEMex MSc Scholarship. Funding was provided by UAEMex and foundation PRODUCE Mexico (Project no. 2200, 2204/ 2005).

1. Fahmy MH, Boucheu JM, Poste LM, Gregorie R, Butter G \& Comeau JE (1992) J Anim Sci 70, 1365-1374.

2. American Meat Science Association (1995) Research Guidelines for Cookery, Sensory Evaluation and Instrumental Tenderness Measurements of Fresh Meat. Chicago, IL: National Live Stock and Meat Board.

3. Hatfield PG, Field RA, Hopkins JA \& Kott RW (2000) J Anim Sci 78, 1779-1785.

4. Olfaz M, Ocak N, Erener G, Cam MA \& Garipoghu AV (2005) Meat Sci 70, 7-14.

5. Borton RJ, Loerch SC, McClure KE \& Wulf DM (2005) J Anim Sci 83, 679-685. 